\title{
Isolated Russell Body Duodenitis with Concurrent Helicobacter Pylori Gastritis
}

\author{
Derrick Chen ${ }^{\mathrm{a}}$, Prashanthi Thota ${ }^{\mathrm{b}}$, Xiuli Liu ${ }^{\mathrm{a}, \mathrm{c}}$
}

\begin{abstract}
Russell body duodenitis (RBD) is a rare entity characterized by the accumulation of numerous cells with Russell bodies (RB) in the duodenal mucosa. The two previously reported cases were not associated with $H$. pylori infection. Herein, we report a case of RBD in a 59-year-old female patient with concurrent $H$. pylori gastritis. The polytypic nature of RB-containing plasma cells and the lack of immunoreactivity for cytokeratin indicate a benign nature. Our findings also support the notion that defective excretion of immunoglobulin, rather than the accumulation of $H$. pylori, is the underlying mechanism for RB formation.
\end{abstract}

Keywords: Plasma cell; Russell body; Helicobacter pylori; Gastritis; Duodenitis

\section{Introduction}

Russell body duodenitis (RBD) is a rare entity that was first reported by Savage et al in 2011 [1] and then later by Paniz Mondolfi et al in 2012 [2]. Both cases described the accumulation of numerous cells with Russell bodies (RB), initially characterized by Russell in 1890 [3], which expanded the duodenal lamina propria in the absence of Helicobacter pylori infection. The RB-containing cell was determined to be a plasma cell by its CD138 immunoreactivity, and exhibited a polytypic pattern of immunohistochemical staining for kappa and lambda light chains $[1,2]$. Prior to this, collec-

\footnotetext{
Manuscript accepted for publication September 24, 2012

${ }^{a}$ Department of Anatomic Pathology, Cleveland Clinic, Cleveland, Ohio, USA

${ }^{\mathrm{b}}$ Gastroenterology, Digestive Disease Institute, Cleveland Clinic, Cleveland, Ohio, USA

${ }^{\mathrm{c} C}$ Corresponding author: Xiuli Liu, Cleveland Clinic, Lerner College of Medicine of Case Western Reserve University, 9500 Euclid Avenue/

L25, Cleveland, Ohio 44195, USA. Email: liux3@ccf.org
}

doi: http://dx.doi.org/10.4021/jmc905w tions of RBs had been documented to occur in the stomach, termed Russell body gastritis (RBG) by Tazawa and Tsutsumi in 1998 [4], where the majority of cases, but not all, were associated with $H$. pylori [5].

In this article, we present a case of isolated Russell body duodenitis with associated $H$. pylori gastritis in a 59-yearold female patient. Review of the English literature indicates that this will be the first report of isolated RBD occurring in conjunction with $H$. pylori infection, and, in addition to the two cases mentioned previously, it will be the third report of RBD overall.

\section{Case Report}

\section{Clinical information and endoscopic findings}

A 59-year-old African American woman presented to the Gastroenterology clinic with epigastric pain, bloating and diarrhea of several years duration. There was partial relief with administration of Omeprazole $40 \mathrm{mg}$ once daily. Her past medical history was significant for gastroesophageal reflux disease, diabetes mellitus, chronic obstructive pulmonary disease, hypertension and obesity. Her past surgical history was remarkable for left mastectomy for breast cancer and abdominal hysterectomy. She quit smoking 5 years prior to presentation after a 20-pack-year smoking history. She denied any alcohol use.

The physical examination was unremarkable. Laboratory studies showed normal complete blood count, serum electrolytes and liver enzymes. An esophagogastroduodenoscopy (EGD) and a colonoscopy were performed. The EGD revealed a normal appearing esophagus and stomach, with nodular mucosa in the duodenum (Fig. 1). Multiple random biopsies were taken from the stomach and the duodenum. The colonoscopy revealed pandiverticulosis and internal hemorrhoids. Random biopsies were obtained from the colon.

\section{Histological and immunohistochemical findings}

HE stained sections from the stomach demonstrated mild 

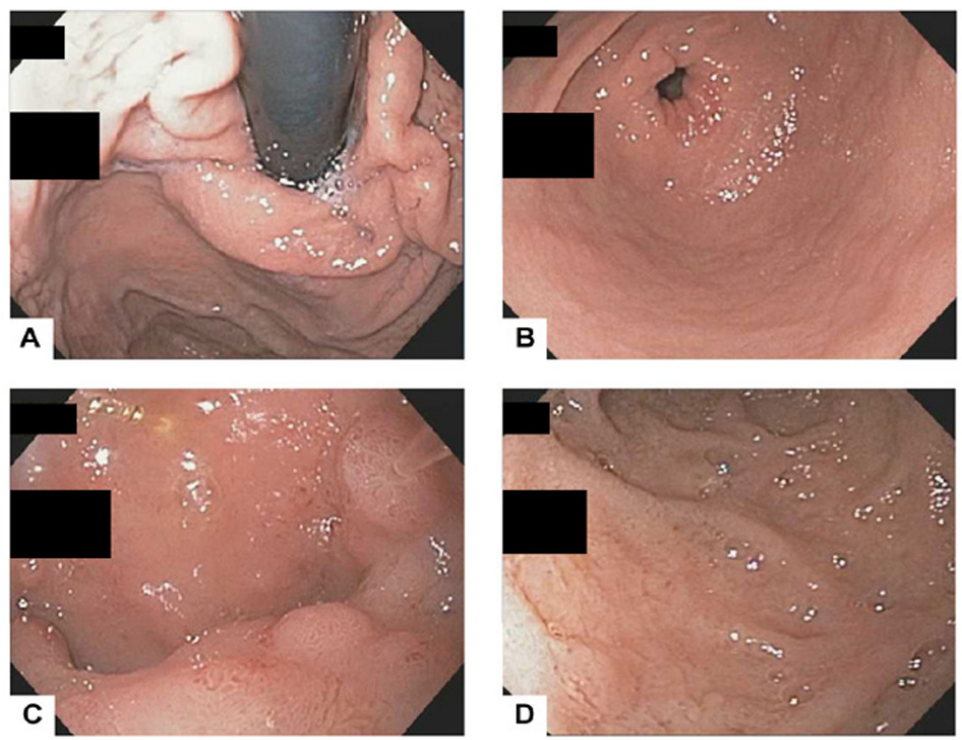

Figure 1. The EGD revealed normal gastric cardia (A) and antrum (B) but mild nodularity in the duodenal bulb (C) and nonspecific duodenitis in the second portion of duodenum (D).
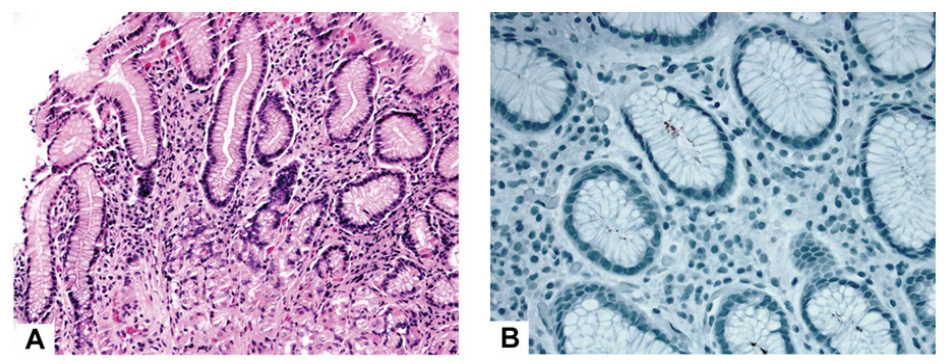

Figure 2. Mild chronic gastritis with patchy activity (A, HE stain, 200×) and the presence of $\mathrm{H}$. pylori organisms (B, immunoperoxidase stain, $400 \times$ ). There were no Russell body-containing plasma cells.
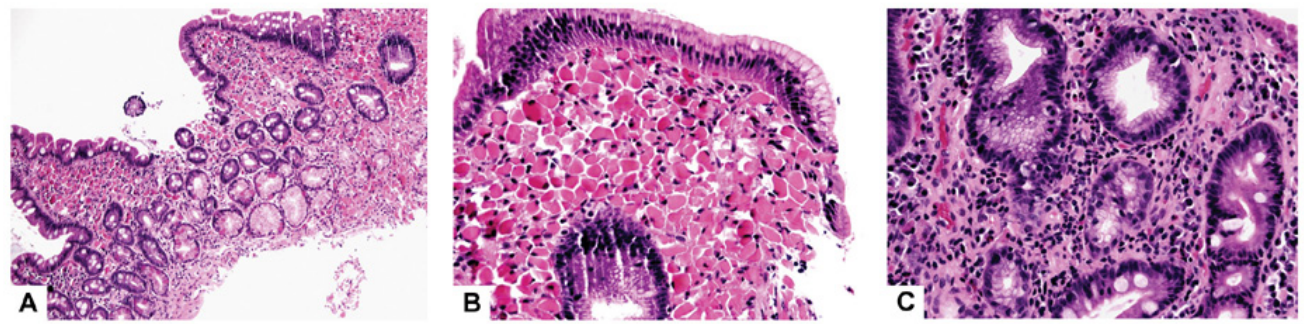

Figure 3. Duodenal mucosa had dense Russell body-containing plasma cells (A, HE stain, 100×; B, HE stain, 400×) in some fragments and Brunner's gland hyperplasia, gastric foveolar metaplasia, and active inflammation in other fragments (C, HE stain, 400×).

chronic gastritis with patchy activity. There was no evidence of Russell bodies (Fig. 2A). A few H. pylori organisms were identified by immunohistochemistry (Fig. 2B). Sections from the duodenum showed fragments of benign duodenal mucosa. Some of the fragments had a dense infiltrate of cells containing numerous Russell bodies in the lamina propria (Fig. 3A, B), and other fragments had focal neutrophilic inflammation, Brunner's gland hyperplasia, and focal gastric foveolar metaplasia (Fig. 3C). No obvious microorganisms, lymphoepithelial lesions, or neoplastic cells were identified. By immunohistochemistry, the RB-containing cells were polytypic for kappa and lambda light chains (Fig. 4A, B), but negative for CD138, CD68, and AE1/AE3 (Fig. 4C, D, E). The overall features were that of mild peptic duodenitis with a dense infiltrate of RB-containing plasma cells. The biopsies from the colon showed no pathological change. 


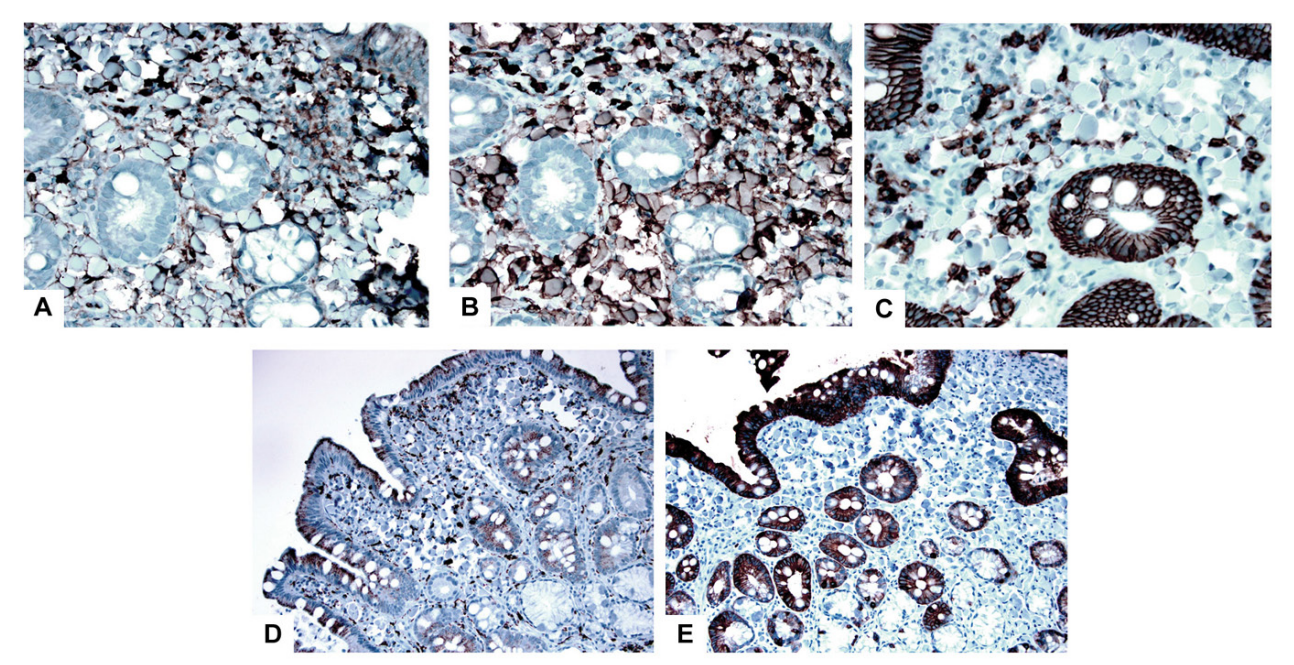

Figure 4. These plasma cells were polytypic for kappa light chain ( $A$, immunoperoxidase stain, $400 \times$ ) and lambda light chain ( $B$, immunoperoxidase stain, 400×) but stained negative for CD138 (C, immunoperoxidase stain, 400×), CD68 and pan-cytokeratin (AE1/AE3) (D and E, immunoperoxidase stain, 200×).

\section{Discussion}

Russell body duodenitis (RBD) is a rare entity that was first reported by Savage et al in 2011 [1] and then later by Paniz Mondolfi et al in 2012 [2]. Herein we report an additional case. The clinicopathologic features of all three cases are summarized in Table 1. Unique to our case is its sole presence in the duodenum as opposed to the stomach, the lack of concurrent Russell body gastritis, and the presence of $H$. pylori infection in the stomach. The cause for Russell bodycontaining plasma cells infiltrating the duodenal lamina propria remains unclear. It may be related to chronic inflammation due to peptic injury as a result of $H$. pylori gastritis. The benign nature of this process is substantiated by the polytypic nature of the RB-containing plasma cells. In the current study, these RB-containing plasma cells were immunonegative for $\mathrm{CD} 138$, which is different from the previous two reports $[1,2]$. This discrepancy may be due to a different type or concentration of antibody used in those studies. However, the CD138 immunonegativity in our case should not argue against the nature of plasma cells, as these cells clearly demonstrated expression of kappa and lambda chains and were not histiocytes. In addition, the immunonegativity for pancytokeratin helped rule out signet ring cell carcinoma.

Similar to the previous reports by Savage et al (2011) [1] and Paniz Mondolfi et al (2012) [2], gastric foveolar metaplasia was also noted in our current case. In addition, we observed Brunner's gland hyperplasia and focal neutrophilic inflammation. These features are consistent with peptic duodenitis. While the case described by Savage NM et al (2011) [1] reported no evidence of H. pylori organisms on routine and toluidine blue staining, the diffuse superficial infiltrates of mononuclear cells in the gastric lamina propria, as presented in their case report, is suggestive of previous $H$. pylori infection or a mild $H$. pylori infection undergoing partial treatment. In such cases, immunohistochemistry may be needed to document $H$. pylori infection. Our results show that chronic peptic duodenitis due to $H$. pylori infection may manifest as RBD. The presence of H. pylori is not required for the formation of Russell body plasma cells, supporting the notion that defective excretion of immunoglobulin, rather than the accumulation of $\mathrm{H}$. pylori, is the underlying mechanism for RB formation.

In summary, we report the first case of isolated Russell body duodenitis with concurrent $H$. pylori gastritis.

\section{References}

1. Savage NM, Fortson T, Schubert M, Chamberlain S, Lee J, Ramalingam P. Isolated Russell body duodenitis. Dig Dis Sci. 2011;56(7):2202-2204.

2. Paniz Mondolfi A, Samuel M, Kikhney J, Moter A, Feldman D, Slova D, Filatov A, et al. Russell body duodenitis: a histopathological and molecular approach to a rare clinical entity. Pathol Res Pract. 2012;208(7):415419.

3. Russell W. An Address on a Characteristic Organism of Cancer. Br Med J. 1890;2(1563):1356-1360.

4. Tazawa K, Tsutsumi Y. Localized accumulation of Russell body-containing plasma cells in gastric mucosa with Helicobacter pylori infection: 'Russell body gastritis'. Pathol Int. 1998;48(3):242-244.

5. Karabagli P, Gokturk HS. Russell body gastritis: case report and review of the literature. J Gastrointestin Liver Dis. 2012;21(1):97-100. 
Table 1. Demographic, Clinical, Endoscopic, and Pathologic Features of Russell Body Duodenitis

Pathologic Features

\begin{tabular}{|c|c|c|}
\hline Author & $\begin{array}{l}\text { Age at } \\
\text { Diagnosis }\end{array}$ & Sex Clinical Features \\
\hline
\end{tabular}

Endoscop
Features

Immunophenotype

Stomach Duodenum

of Russel body containing plasma cells

\begin{tabular}{|c|c|c|c|c|c|c|c|}
\hline $\begin{array}{l}\text { Savage et } \\
\text { al, } 2011\end{array}$ & $55 \mathrm{yrs}$ & $\mathrm{M}$ & $\begin{array}{l}\text { 2-week history } \\
\text { abdominal pain; } \\
\text { HIV positive with } \\
\text { undetectable viral } \\
\text { load and CD4 of } \\
514 / \mathrm{mm}^{3} \text {; history } \\
\text { of lymphoma (5- } \\
\text { year remission) }\end{array}$ & $\begin{array}{l}\text { Non-specific } \\
\text { gastritis and } \\
\text { duodenitis } \\
\text { without } \\
\text { identifiable } \\
\text { mass }\end{array}$ & $\begin{array}{l}\text { Mild } \\
\text { chronic } \\
\text { gastritis, } \\
\text { no Russell } \\
\text { bodies, } \\
\text { negative } \\
\text { for } H . \\
\text { pylori }\end{array}$ & $\begin{array}{l}\text { Duodenal } \\
\text { mucosa with } \\
\text { dense infiltrate } \\
\text { of plasma } \\
\text { cells in lamina } \\
\text { propria that } \\
\text { contained } \\
\text { numerous } \\
\text { Russell } \\
\text { bodies, } \\
\text { mild peptic } \\
\text { duodenitis }\end{array}$ & $\begin{array}{l}\text { CD138+, cytokeratin-, } \\
\text { polytypic kappa and } \\
\text { lambda }\end{array}$ \\
\hline $\begin{array}{l}\text { Paniz } \\
\text { Mondolfi et } \\
\text { al, } 2012\end{array}$ & $69 \mathrm{yrs}$ & $\mathrm{F}$ & $\begin{array}{l}\text { Multiple complaints } \\
\text { of dysphagia with } \\
\text { prior endoscopy } \\
\text { showing Schatzki } \\
\text { ring, and } \\
\text { repeat showing } \\
\text { esophagitis and } \\
\text { gastroduodenitis; } \\
\text { history of Crohn's } \\
\text { disease, cirrhosis, } \\
\text { rheumatoid } \\
\text { arthritis, morbid } \\
\text { obesity with sleeve } \\
\text { gastrectomy }\end{array}$ & $\begin{array}{l}\text { Nodule within } \\
\text { duodenal bulb }\end{array}$ & $\begin{array}{l}\text { Negative } \\
\text { for } H \text {. } \\
\text { pylori }\end{array}$ & $\begin{array}{l}\text { Enteric-type } \\
\text { mucosa } \\
\text { with gastric } \\
\text { metaplasia } \\
\text { and numerous } \\
\text { lamina propria } \\
\text { plasma cells } \\
\text { containing } \\
\text { Russell bodies }\end{array}$ & $\begin{array}{l}\text { CD138+, CD68-, } \\
\text { polytypic kappa and } \\
\text { lambda }\end{array}$ \\
\hline $\begin{array}{l}\text { Current } \\
\text { study }\end{array}$ & $59 \mathrm{yrs}$ & $\mathrm{F}$ & $\begin{array}{l}\text { Epigastric pain, } \\
\text { bloating, and } \\
\text { diarrhea of several } \\
\text { years duration; } \\
\text { history of type II } \\
\text { diabetes mellitus, } \\
\text { gastroesophageal } \\
\text { reflux disease and } \\
\text { irritable bowel } \\
\text { syndrome, and } \\
\text { chronic obstruction } \\
\text { pulmonary disease }\end{array}$ & $\begin{array}{l}\text { Nodular } \\
\text { mucosa in the } \\
\text { duodenum, } \\
\text { normal } \\
\text { appearing } \\
\text { esophagus } \\
\text { and stomach }\end{array}$ & $\begin{array}{l}\text { Mild } \\
\text { chronic } \\
\text { gastritis } \\
\text { with } \\
\text { patchy } \\
\text { activity, } \\
\text { no Russell } \\
\text { bodies, } \\
\text { positive } \\
\text { for } H \text {. } \\
\text { pylori }\end{array}$ & $\begin{array}{l}\text { Duodenal } \\
\text { mucosa } \\
\text { with dense } \\
\text { infiltrate of } \\
\text { Russell body } \\
\text { containing } \\
\text { plasma cells } \\
\text { in lamina } \\
\text { propria, } \\
\text { mild peptic } \\
\text { duodenitis }\end{array}$ & $\begin{array}{l}\text { CD138-, CD68-, } \\
\text { AE1/AE3-, polytypic } \\
\text { kappa and lambda }\end{array}$ \\
\hline
\end{tabular}

